\title{
Evaluation of Internal Control Activities Operating Income On Technical Implementation Unit (UPTD) Terminal Joyoboyo Surabaya
}

Yanna Eka Pratiwi, Supartini

Faculty of Economics Merdeka University Surabaya

Email: yannapratiwiy@gmail.com

\begin{tabular}{|c|c|c|}
\hline Accepted : & Reviewed : & Published : \\
January, 11 2018 & February, 13 2018 & March,30 2018 \\
\hline
\end{tabular}

\begin{abstract}
Purpose: This research is to determine whether the application of internal control activities on operating income has been running effectively.

Design/methodology/approach: This research method using quantitative analysis of the factors which is causing a problem, for that we need the internal control over operating income, and using qualitative data analysis techniques in order to determine as to whether the evaluation of internal control penapatan reception operations have been implemented effectively.
\end{abstract}

Findings: The results of this study indicate that the implementation of the internal control on the Terminal UPTD Joyoboyo can not be implemented.

Research limitations/implications: The implementation of internal control can only be done if the amendment to the accounting system as well as the separation of the functions necessary to anticipate the implications.

Practical implications: expected by the authors is the need to change the system accounting is centralized to decentralized, monitoring needs to be optimized, it is expected the separation of the functions to avoid geminating functions.

Originality/value: This research combines Technical Implementation Unit (UPTD) Terminal Joyoboyo Surabaya.

Paper type: Research paper

Keywords: Accounting Systems, Internal Control, Revenue Operating Income.

\section{INTRODUCTION}

Public sector organizations have a role that is different from the business organization in general. Mardiasmo (2002: 02) states that from the standpoint of public sector economics can be understood an entity whose activities are related to the business of producing goods and public services in order to meet public needs and rights. Some of the duties and functions of the public sector in fact can also be done by the private sector, but for specific tasks where the public sector can not be replaced by the private sector. Public sector organization is

Evaluation of Internal Control Activities Operating Income On Technical Implementation Unit (UPTD)

Terminal Joyoboyo Surabaya

Yanna Ika Pratiwi, Supartini 
currently facing pressure to more efficiently take into account the economic costs and social costs, and its ability to fulfill the provision of services to the community.

Similarly, the terminal UPTD Joyoboyo which are required to be always able to overcome any pressure that appears to choose the right strategy and calculate enough about the steps to be taken. Organization of internal control is one way that can be done by way of an evaluation to see whether the organization's activities during the course of this according to the "masterplan"that had been developed previously. Evaluation should be carried out not only once but continuously on a periodic basis. Internal control system has several purposes, among others: the reliability of financial information, compliance with laws and regulations, effectiveness and efficiency of operations. This goal can be achieved if the elements of the system are met, among other elements: 1) Environment Control, 2) Risk Assessment, 3) Information and Communication, 4) Control Activities, and 5) Monitoring.

Activity in the business can be broadly divided into four, among others: the revenue cycle, the expenditure cycle, the production cycle and financial cycle (Bodnar, 2000:174). The four cycles above have positions and roles that are equally important, but the most frequently under the spotlight is the revenue cycle. The company's revenue cycle is a series of events related to the distribution of goods and services to others as well as payments related billing(Mahrus, Bambang Wicaksono, Nurlina, Cholil, \& Sri Wiwoho, 2017). This cycle becomes very prone to misuse because it generates current assets are cash and receivables that have liquid properties.

\section{METHODS}

Quantitative analysis which are factors that cause the problem, for that we need the internal control over operating income, and using qualitative data analysis techniques in order to determine as to whether the evaluation of internal control penapatan reception operations have been implemented effectively. This study uses descriptive qualitative research approach where the data obtained will be processed to analyze the problems in research.

\section{DISCUSSION}

Surabaya has two (2) Passenger Terminal Type A (Terminal Purabaya and Tambak Oso Wilangun), 1 (one) Terminal Type B (Terminal Joyoboyo) and 1 Terminal Type C (Terminal Bratang) and several Sub Terminals and Base scattered the whole area of Surabaya. With the terminal facility is expected Surabaya City community in particular and society in general can use the transportation service to and from the desired destination. Terminal which is the object of this study is Terknis Implementation Unit Office Terminal (UPTD) Joyoboyo terminal owned by the Government of East Java Province, located in the Surabaya City Government is located at JL. Joyoboyo No. 01 Surabaya. Joyoboyo terminal was built in 1969, located in the southern part of Surabaya city center with an area ofterminal. \pm 1.2 ha At its inception, Terminal Joyoboyo a passenger terminal with type "A" .Terminal Passenger Type "A" is the terminal that function to serve public transportation for inter-city transportation between provinces and / or cross-border transport, inter-city transportation in the province, city transport and angkuatan countryside.

Evaluation of Internal Control Activities Operating Income On Technical Implementation Unit (UPTD) 
In line with the development of Surabaya City, Terminal Joyoboyo that its capacity has been inadequate, and location in the middle of the city so that in 1990 was built Terminal Purabaya and by virtue of the Agreement Governor Head. Tk. I JATIM Number: 645.7 / 9605/210/1982 dated 26 April 1982 and the MOC Letter No. 13 135 / AJ.100 / MOC dated February 9, 1989 dilaksanakanlah Public Transport Terminal development in Village Bungurasih Inter-City, to replace Terminal Joyoboyo. Furthermore Terminal status Joyoboyo fell into a passenger terminal with a type "B" which is technically advantageous because Joyoboyo Terminal adjacent to Wonokromo Station, Market Wonokromo and Surabaya Zoo. Terminal passengers with a type "B" is a passenger terminal that serves only serve the public vehicle for inter-city transportation in the province, city transport and / or rural. UPTD Joyoboyo Terminal located on the street No.01 Joyoboyo Surabaya, with boundaries.

\section{Terminal facilities Joyoboyo}

In conducting its operational activities in addition be supported by human resources or qualified personnel must also be supported by an adequate infrastructure for the creation of safety and convenience of visitors terminals. Facilities owned by Terminal Joyoboyo among others: Police Wonokromo Ka UPTD Space Station, DPC Office ORGANDA, Levy Post, Post Vehicle Setup, Pos DAMRI, Mushollah, Care Goods, Kiosk, Ponten and Public Telephone. While the number of public transportation fleets in UPTD Terminal Joyoboyo, among others:

Table 1 - Total Fleet public transportation

\begin{tabular}{|c|c|l|c|c|}
\hline No. & LYN & \multicolumn{1}{|c|}{ DEPARTMENT } & $\begin{array}{c}\text { AmountFle } \\
\text { et }\end{array}$ & Description \\
\hline 1 & P & Joyoboyo- KarangMenjangan & 162 & 50 \\
\hline 2 & GL & Joyoboyo - Ps.Loak - Kedungdoro - RSAL & 125 & \\
\hline 3 & Y & Joyoboyo - Jl.Demak - Banyu Urip & 61 & \\
\hline 4 & H 4.J & Joyoboyo - Rungkut - Sedati & 139 & \\
\hline 5 & M & Joyoboyo - Undaan - JMP & 120 & \\
\hline 6 & S & Joyoboyo - Bratang - Kenjeran & 140 & \\
\hline 7 & U & Joyoboyo - Long Jiwo - Rungkut & 57 & Terminal Bratang \\
\hline 8 & V & Joyoboyo - Cotton Krampung - Tambak Rejo & 127 & \\
\hline 9 & JBM & Joyoboyo - Bratang - Medokan - Gunung.Anyar & 137 & \\
\hline 10 & JTK & Joyoboyo - Margorejo - Industry - UPN & & \\
\hline 11 & F & Joyoboyo - THR - Indrosono & & \\
\hline 12 & X & Joyoboyo - Nail Factory - Gedongan & & \\
\hline 13 & D & Joyoboyo - Pasar Turi - Sidorame & & \\
\hline
\end{tabular}




\begin{tabular}{|c|c|l|c|c|}
\hline 14 & T.1 & Joyoboyo - Kupang - Sawahan - Simo P & 55 & \\
\hline 15 & T.2 & Joyoboyo - Karangmenjangan - Mulyosari & 81 & \\
\hline 16 & J & Joyoboyo - Jl. Demak & 60 & \\
\hline 17 & JK & Joyoboyo - Kalijudan - Kenjeran & 58 & \\
\hline 18 & JM & Joyoboyo - Menganti & 101 & \\
\hline 19 & TV. OLD & Joyoboyo - Balongsari - Manukan & 50 & \\
\hline 20 & TV. NEW & Joyoboyo - Balongsari - Manukan & 119 & $\begin{array}{l}\text { Base } \\
\text { Hamlet.Kupang }\end{array}$ \\
\hline 21 & W & Dukuh Kupang Rejo - Tambak & 100 & $\begin{array}{l}\text { Base } \\
\text { Kupang }\end{array}$ \\
\hline 22 & WL & DukuhKupang - KarangMenjangan \\
\hline 23 & RDK & Rungkut - DukuhKupang & 50 & $\begin{array}{l}\text { DukuhBase. } \\
\text { Kupang }\end{array}$ \\
\hline
\end{tabular}

\begin{tabular}{|c|c|l|c|c|}
\hline No & LYN & \multicolumn{1}{|c|}{ Programs } & Total Fleet & Description \\
\hline 24 & DKB & Dukuh Kupang & 20 & Base DkKupang \\
\hline 25 & MGD & DukuhKupang - Menganggal & 50 & Base Menanggal \\
\hline 26 & H 2.4 & Market Wonokromo -Menanggal & 33 & \\
\hline 27 & BK & all-roundBangkingan & 12 & \\
\hline 28 & F & Market Wonokromo - Indrosono & 52 & \\
\hline 29 & I & Kupang - Tandes & 60 & \\
\hline 30 & E-1 & Bungurasih - Joyoboyo & 23 & \\
\hline 31 & E-2 & Joyoboyo - Red Bridge & 11 & \\
\hline 32 & MJK & Mojokerto - Joyoboyo & & \\
\hline
\end{tabular}

Source: Internal Data

\section{Terminal Joyoboyo UPTD workforce}

Data on workforce obtained from the Secretariat UPTD Joyoboyo Terminal. Employee (employees) UPTD Terminal Joyoboyo until June 2007 was 105 people consisting of Terminal Joyoboyo: 68, Terminal Bratang: 18, 
Terminal Kenjeran: 3, Base Menanggal: 5 people, Base DukuhKupang:5 people, Base Market Wonokromo: 4 people and Petojo Base:2orang

\section{Joyoboyo Terminal UPTD organizational Structure}

the organizational structure of the Vendor is a systematic overview of the main tasks, responsibilities and functions and relationships in a business organization, which aims to make the organization more focused activities in achieving its objectives. Terminal UPTD Joyoboyo have lines or stripes organizational structure that is a form of organization in which there are lines of authority linking directly vertically between superiors and subordinates. So starting from the highest to the leadership of the organization is at its lowest position, between one another, each connected to one line of authority or command line. Each subunit has a responsibility to report to the head unit one level above.

Based on the Decree of the Mayor of Surabaya Number 36 Year 2006 concerning Organization Office Technical Implementation Unit Terminal In the Transportation Department of Surabaya, which henceforth UPTD Terminals is implementing elements of technical and operational Office in management of terminals, each UPTD that in carrying out the task that lies beneath and responsible to the Head of Department (Roesli, Heri, \& Rahayu, 2017). Based on the decree of the mayor, the organizational structure UPTD Joyoboyo Terminal consists of Chief UPTD, the Secretariat, the Sub Unit Revenues, Terminal Procedures Sub Unit, Sub Order and Safety Unit and Base.

\section{Duties}

In accordance with the decision of the Mayor of Surabaya No. 36 of 2006 on the Organization of the Technical Implementation Unit Surabaya City Department of Transportation, the description of tasks and functions in the terminal part as Head UPTD Joyoboyo is obliged to lead and coordinate all activities of the implementing agency UPTD staff. In performing its duties the Head UPTD under and responsible to the Head of Department. The Secretariat headed by the Secretary in carrying out duties under and responsible to the Head UPTD. The Secretary has the task: Develop plans and activities UPTD; Implement financial affairs, home appliances, fixtures and equipment as well as office cleaning; Implement personnel administration; Implementing the institutional development and management; Implement receipts and deposits levies and other local revenues to the local treasury; Coordinate the preparation of reports; Carry out other tasks given by the Head of UPTD in accordance with its duties and functions.

a. Sub Unit

EachSub Unit headed by a Head of Sub Unit in carrying out duties under and responsible to the Head UPTD.

b. Sub UnitRevenue

Sub Units Revenuehas the task:

1. Implement sales Payment alerts Retribution (TPR) terminal, fee collection and other lawful income areas as well as to deposit cash into the area;

2. Prepare reports on executing the task;

3. Carry out other tasks given by the Head of UPTD in accordance with its duties and functions.

Evaluation of Internal Control Activities Operating Income On Technical Implementation Unit (UPTD) 
c. Sub UnitTata Terminal

Sub Unit TataTerminal Has the task:

1. Set the circulation of vehicles and people in the terminal;

2. Implement recording the number of the flow of vehicles and passengers is up / down and in / out terminals;

3. Implement arrangements arrival and departure of vehicles according to a set schedule;

4. Melaksanakn administrative completeness check of vehicles (STUK, control cards and an hour drive) technical requirements and road worthy vehicles as well as the completeness of the vehicle;

5. Implement record keeping and reporting of budgeting;

6. Carry out other tasks given by the Head of UPTD conformed to the duties and functions.

d. SubOrder and Safety Unit

SubOrder and Safety Unit has the task:

1. Implement security and policing in the terminal;

2. To supervise the terminal;

3. Coordinate with related agencies for handling security and order;

4. Carry out other tasks given by the Head of UPTD in accordance with its duties and functions.

e. Bases

Each base led by a Head base in carrying out duties under and responsible to the Head UPTD.

Base has the task:

1. Helping UPTD implementation of activities within the scope of the smaller area;

2. Implement hygiene and security bases;

3. Implement evaluation and reporting of the implementation of tasks;

4. Carry out other tasks given by the Head of UPTD in accordance with its duties and functions.

\section{a. Activities UPTD Joyoboyo Terminal}

Terminal Joyoboyo UPTD operational area includes: Bratang Terminal, Terminal Kenjeran, Menanggal Base, Base Dukuh Kupang, Wonokromo Market Base and Base Petojo. Joyoboyo airport public transport terminal for Inter-City Transportation In Province (AKDP). Public Transportation (Buses and microbus / public transportation) and Taxi Transport and Angguna. UPTD Joyoboyo Terminal is an organization working in the field of terminal services. Based on the Surabaya Mayor Decree 51 of 2001 on details of Duties and Functions of Surabaya City Department of Transportation, then UPTD Terminal has the task, among others: Organizing the management of terminal / base; Carry out maintenance and cleanliness of the terminal / base; Implementing the fee collection and other lawful income areas relating to the management terminal / base; Carry out policing and security at the terminal / base; Regulating the circulation of vehicles and people in the terminal / base; Implement recording the number of the flow of vehicles and passengers is up / down vehicles along the exit / entry terminal / base; Implement arrangements arrival and departure of vehicles according to a predetermined schedule; Implement traffic management in terminal control area / base; Carry out administrative completeness check of vehicles (STUK, and Time Travel Monitoring Card), technical and road worthy vehicles as well as the 
completeness of the other vehicle; Carry out supervision on transport fares tailored to the type of services provided; Implement record keeping and reporting violations; Carry out administration for; Carry out other duties assigned by the Head of Department.

\section{Funding}

The funding system at Terminal UPTD Joyoboyo come from the central office. Terminal Joyoboyo an Implementation Unit of the Department engaged in the provision of passenger terminal services. Centralized organizational system terminal, so all expenditure or financing of operations derived from the central terminal, the Transportation Department of Surabaya domiciled in Jl.Dukuh Menanggal No.01 Surabaya. Activities UPTD Joyoboyo Terminal is only held terminal management and holding activities of fee collection terminal, while any costs incurred in carrying out the activities are all derived from the central office. UPTD Joyoboyo Terminal is only entitled to make a report targets and realization of annual revenue budget alone.

\section{B. PRINCIPLES AND GOALS IN THE DETERMINATION OF THE STRUCTURE AND RATES OF RECEIPT AMOUNT OF OPERATING INCOME TO TERMINALUPTD}

subjectlevies are individuals or entities that obtain service terminal facilities. The level of service is measured based on the frequency of use, comprehensive and terminal facilities service period. Surabaya City Regional Regulation No. 7 of 2001 on levies Terminal, the principles and objectives in setting the levy rate basarnya structure based on the objective to obtain a decent profit in lieu of management fees, costs, fees cleanliness, security fees and administrative costs. The structure and size of the tariff is determined as follows:

1. The loading and unloading of passengers or goods for general passenger cars and public buses car:

a. For cars fast inter-city public bus every sign of Rp.1000,00 (one thousand rupiah);

b. For car slow inter-city public bus every sign of Rp. 500.00 (five hundred rupiah);

c. For inter-city public transportation every sign of Rp. 300.00 (three hundred rupiah);

d. For public bus transport car city every sign of Rp. 300.00 (three hundred rupiah);

e. For general passenger cars not in the stretch (Taxi and Angguna) each entry Rp. 300.00 (three hundred rupiah);

f. For general passenger car city transport every time you sign Sub Terminal:

With farthest stretch 15 kilometers Rp. 150.00 (one hundred fifty rupiah) and to stretch more than 15 kilometers of Rp. 250.00 (two hundred fifty rupiah) provided that any return trip along the trajectory determined only subject to a levy of 1 (one).

2. Park:

a. Bicycle Rp. 100.00 (one hundred rupiah);

b. Motorcycle Rp. 300.00 (three hundred rupiah) once parking for the first 2 hours, and Rp. 100.00 (one hundred rupiah) for each subsequent hour; 
c. Private cars Rp. 1,000.00 (one thousand rupiah) once parking for the first 2 hours, and Rp. 300.00 (three hundred rupiahs) for each subsequent hour;

d. Car Pick Up / Bis mini Rp. 1,000.00 (one thousand rupiah) once parking for the first 2 hours, and Rp. 300.00 (three hundred rupiahs) for each subsequent hour;

e. Bus parking on the long path / track breaks Rp. 2000.00 (two thousand rupiah);

f. Overnight bus Rp. 5000.00 (five thousand rupiah).

3. Kiosk:

a. For use in passenger terminal kiosk type "A" every square meter of Rp. 300.00 (three hundred rupiah) every day and at the Passenger Terminal type "B" and "C" every square meter of Rp. 200.00 (two hundred Rupiah) per day;

b. In addition to the fees imposed levies on:

1. The use of water and electricity in accordance applicable tariffs and maintenance charges of drinking water and electricity the plant by $10 \%$ (ten percent) of the imposition;

2. Reimbursement of Land and Building Tax (PBB) in accordance with the applicable regulations through Terminal Sub Office at the Department of Transportation.

4. Means of Public Cleanliness:

a. bathroom or lavatory Rp. 500.00 (five hundred rupiah).

b. Peturasan Rp. 300.00 (three hundred rupiahs).

5. Public Transport crew Resting place:

a. less than or up to the first 6 hours of Rp. 1,000.00 (one thousand rupiah);

b. Less than or every 6 hours later Rp. 1,000.00 (one thousand rupiah).

6. Places Advertising:

Use of place billboards in the Passenger Terminal Type "A" Rp. 5000.00 (five thousand rupiah) per square meter per month and at theTerminal

PassengerType "B" amounting to Rp. 2,500.00 (two thousand five hundred rupiah) per square meter per month.

7. Passengers and Visitors Waiting Room:

For every person Rp.200,00 (two hundred rupiah) every time you sign in. But specific to Terminal Joyoboyo no polling services waiting room.

8. Licensing:

a. For every gift or usage license renewal kiosks or other terminal facilities amounting to Rp. 10,000.00 (ten thousand rupiah);

b. Permit referred to in point (1) shall be valid for two (2) years. 


\section{APPLICATION PROCEDURES AND INTERNAL CONTROL SYSTEM FOR OPERATING INCOME}

Receipts operating income at Terminal UPTD Joyoboyo derived from levies Terminal. Systems operating income receipts on Terminal UPTD Joyoboyo presented in the following figure Revenue Receipt Description Levies On Terminal Joyoboyo:

1. Ka. Unit Pendaapatan take the ticket levy (TPR) to the Transportation Department of Surabaya City.

2. Ka Unit distributes income to each commander TPR Team (No 3) and bases there.

3. Each commander Team members share the TPR to exist in every post (there are 6 posts) spread Terminal Joyoboyo,

4. Each team whose members are at their posts in selling tickets retribution TPR (TPR) to any incoming fleet of public transportation in the Terminal.

5. TPR archives each post calculate, report and deposit the sale proceeds amount to each commander Team TPR respectively.

6. Each team is known commander Ka archives handed Revenue Unit TPR and depositing the proceeds to the Secretary keesok TPR day.

7. Yng Secretary serves as Treasurer, together with members calculate archives and matched with the amount of money available.

8. Secretary summarize and make daily reports the total number of sales TPR of each team and also commander of each base.

9. Daily reports that there are reported and validated by Ka UPTD Joyoboyo Terminal.

10. Every three (3) days once the Secretary, together with members of depositing the amount of sales proceeds to the Bank TPR JATIM through DISHUB Surabaya.

11. Furthermore, the proceeds will go to the cash TPR Urban Surabaya that will add revenue (local revenue).

Revenue Receipt Description Levies On Each Base:

1. All Bases take the ticket levy (TPR) in Teminal Joyoboyo.

2. Ticket levy is distributed to each member.

3. Members do sales levy to each incoming fleet.

4. Members report the proceeds to the head. Base.

5. Create a daily report of the sale of TPR and report to Terminal Joyoboyo accompanied by archive on the next keesok.

Description Kiosks and Advertising Revenue Receipts:

1. Each stall owner and billboards that exist in Terminal Joyoboyo and all bases are depositing the rent to the Secretary in accordance with a predefined rate.

2. Secretary make a statement proceeds.

3. Reported and known by Ka. Terminal UPTD Joyoboyo. 
4. Secretary of depositing the proceeds to the Bank Jatim through Surabaya City Department of Transportation in conjunction with the sale of Retribution (TPR).

\section{TARGET AND REALIZATION OF BUDGET REVENUE OPERATING INCOME}

The following is a report revenue budget targets and the realization of operating income in 2005 and 2006: Revenue Budget Realization in 2005 In UPTD. Terminal Joyoboyo.
JANUARY:
Rp. 53.73345 million, -
FEBRUARY:
Rp. 47.91455 million, -
MARCH:
Rp. 49.01695 million, -
APRIL:
Rp. 51.2459 million, -
MEI:
Rp. 51.8745 million, -
JUNE:
Rp. 49.34345 million, -
JULY:
Rp. 51.4281 million, -
AUGUST:
Rp. 52.04075 million, -
SEPTEMBER:
Rp. 49.5447 million, -
OCTOBER
Rp. 49.43035 million, -
NOVEMBER:
Rp. 43.636 million, -
DECEMBER:
Rp. 47.6847 million, -
TOTAL
:Rp. 596893 400, -
TARGET 2005
:Rp. 968000 000, -

Based on the above report can be seen that the target set in 2005 can not be met.

Table 2 - Changes in the Budget Plan 2006 Fiscal Year Revenue

\begin{tabular}{|c|c|c|c|c|c|}
\hline $\begin{array}{c}\text { CodeR } \\
\text { eke- } \\
\text { ning }\end{array}$ & Descriptionrevenues & budgetOriginally & $\begin{array}{l}\text { Additions / } \\
\text { Deductions }\end{array}$ & $\begin{array}{c}\text { Budgets After } \\
\text { PAK }\end{array}$ & Basic Law / Details \\
\hline & $\begin{array}{l}\text { Levy Terminal } \\
\text { Joyoboyo }\end{array}$ & Rp. 756414 000, - & $\begin{array}{l}\text { USD. } 226077650 \text {, } \\
\text { - }\end{array}$ & $\begin{array}{l}\text { USD. } 530336 \\
350,-\end{array}$ & $\begin{array}{l}\text { Surabaya Regional } \\
\text { Regulation No. } 7 \text { of } \\
2001 \text { on levies } \\
\text { Terminal. }\end{array}$ \\
\hline & $\begin{array}{l}\text { Kiosk Terminal } \\
\text { Joyoboyo }\end{array}$ & Rp. $35,447,113,-$ & USD. 9.500.000, - & Rp. 44,947,113, - & Details Attached \\
\hline & $\begin{array}{l}\text { Ponten Terminal } \\
\text { Joyoboyo }\end{array}$ & $\begin{array}{l}\text { Rp. } 29.1056 \\
\text { million, - }\end{array}$ & $\begin{array}{l}\text { USD. } 2.3514 \\
\text { million, - }\end{array}$ & $\begin{array}{l}\text { USD. } 31.457 \\
\text { million, - }\end{array}$ & Breakdown ofAttached \\
\hline & $\begin{array}{l}\text { Advertising } \\
\text { TerminalJoyoboyo }\end{array}$ & Rp. 3.684 million, - & - & $\begin{array}{l}\text { Rp. } 3.648 \text { million, } \\
\text { - }\end{array}$ & Details Attached \\
\hline
\end{tabular}

REALIZATION OF BUDGET REVENUE IN 2006

\section{INJoyoboyo UPTD}

JANUARY

TERMINAL:Rp. 52.58275 million, -

FEBRUARY:

Rp. 46.1166 million, -

Evaluation of Internal Control Activities Operating Income On Technical Implementation Unit (UPTD)

Terminal Joyoboyo Surabaya

Yanna Ika Pratiwi, Supartini 
MARCH:

APRIL:

MEI:

JUNE:

JULY:

AUGUST:

SEPTEMBER:

OCTOBER

NOVEMBER:

DECEMBER:

Total Actual Retribution

Levy Kiosk

RetributionToilet

Advertising

Total

Total Entire Realization

Target Budget Th. 2006
Rp. 52.128 million, -

Rp. 49.33405 million, -

Rp. 52.3967 million, -

Rp. 51.5241 million, -

Rp. 52.30605 million, -

Rp. 50.655 million, -

Rp. 49.8433 million, -

Rp. 45.98455 million, -

Rp. 45.31185 million, -

Rp. 48.0788 million, -

\section{PROBLEMS}

In carrying out the activity of an effort to fulfill the expected goals the company is inseparable from the emergence of the problem along with the increasing activity of the company. If the problem is not resolved soon would impede the course of business in achieving the goals of the company. Based on the problems it is a problem is every difficulty that drives humans to solve it.

From the research, the authors found an issue that can not be separated from the research discussed in UPTD include:

1. Lack of control on the flow of operational flowchart receiving income in carrying out the activities of the company, which raised the question in the form of geminating functions performed by a particular function.

2. Supervision and control of the flow chart flowchart revenue receipts is less clear. For example: in practice it turns out sometimes object often do not get a ticket levy levy as proof of payment. These are probably the manipulation of data on the number of vehicles entering the terminal.

3. Systems and procedures are implemented in an existing operating income receipts less meet, because the system that makes them more prone manual abuses. 


\section{E. CAUSE PROBLEMS}

In each of the issues involved, of course, the causes that led to the occurrence of the problem, any problems that arise will impact less favorable to the sustainability of the pace of the company. Therefore, it should be completed as soon as possible so that the problem is not protracted, then for its completion must be subjected to the identification of the problem first, otherwise it will result in less precise solutions applied so that the company wants expectations will not be met.

With the problems of course there is the cause, which became the starting point of these problems. As for causing problems faced by companies in the implementation of internal control in Operational revenue receipts are:

1. a healthy practice can not be implemented due to the presence geminating function in the system of receipts and deposits money.

2. The lack of qualified human resources in implementing the company's activities.

3. Lack of evaluation of the implemented system.

\section{F. DUE TO PROBLEMS}

If there is a problem within a company and not addressed, then the next will bring a result that certainly will disrupt the activity of the company to achieve the goals that have been planned, while the result of the problem is:

1. The lack of supervision and internal control in the chart flowchart operating income receipts resulting negative impact that irregularities in reported total sales levy.

2. Geminating their functions performed by a particular function can lead to violations that may result in reduced amount of revenues that should have been reported. This leads to non-fulfillment of budget targets.

3. User reception system revenues will result in less efficiency activities of receiving income, resulting in poor services.

\section{G. PROBLEM ANALYSIS}

Analysis of means to solve or detailing a specific amount into several elements or parts and determine the relationship between the attitude of those elements alone, in accordance with what has been described in the background of the issues and problems. As for the analysis of the problem according to the authors of existing analysis on companies are:

1. Analysis of Operating Income Revenue System, implementation of internal control UPTD Joyoboyo Terminal can be implemented properly if the amendment to the accounting system from manual towards computerization. Because a system is a certain way to carry out a series of activities.

2. Upon analysis Practice Healthy, good A reception system and perfect will ensure good internal control, if there is no implementation of sound practices in all functions involved in the reception system. Healthy 
practice there can be done by all functions within the system to function properly in accordance with the established procedure.

Healthy practice this can be done if the systems and procedures for acceptance of the company has done a proper separation of functions and systems of authority and a good bookkeeping procedures. With the fulfillment of the above elements, each function will be able to do the matching on the transaction receipt, so if there is a deviation on receipt of the income levy may soon be known. From the analysis of the above problems, it is known that the occurrence of fraud against Operational revenue receipts can be avoided by improving reception system, so as to meet the elements of good internal control.

\section{H. RESOLUTION}

After knowing of the problems that exist in UPTD Terminal Joyoboyo, knowing the cause of the problem and the consequences arising out of the problem, the authors provide troubleshooting as follows: Changes in the system of internal control and accounting systems from manual systems to the computerized system is necessary to solve the problem that is, other than that it is also necessary current flow receiving income. It also greatly affect is the separation of the functions in the company to avoid any geminating function, because a control system would work better if there is a separation of functions within the company, so as to facilitate control over internal control. The accounting system is the application or the realization of the internal control, while embodiments are:

1. accounting system will separate the parts in accordance with the duties and responsibilities. Here will be apparent that the accounting system of internal control to apply a destination that is the organizational structure that separates responsibility and healthy practices in running the company's operations.

With the formulation of the accounting system means control of the accounting and administrative controls will be easier.With the formulation of the accounting system means that supervision will be easier, because the accounting system has separated the parts concerned and procedures are clear. The current flow of income receipts should mepunyai strict separation of functions in order to avoid duplicate functions in running the assigned task.

\section{CONCLUSION}

Based on the analysis and discussion on the implementation of internal controls in the accounting system acceptance. Joyoboyo terminal is one terminal Office Technical Implementation Unit in the transportation bureau of Surabaya. Terminal UPTD Joyoboyo funding system comes from the Department of Transportation's headquarters city of Surabaya. So the activity of Terminal UPTD Joyoboyo only carry out operational activities and report budget targets and realization of operating income only. From the analysis and discussion of the above shows that in achieving corporate goals required an adequate internal control system to solve the problems in the company. Internal control over operating income receipts until now difficult to be implemented at Terminal Joyoboyo because the accounting system is still centralized and still their geminating functions.

Evaluation of Internal Control Activities Operating Income On Technical Implementation Unit (UPTD) 
Implementation of internal control UPTD Joyoboyo Terminal can be implemented if the amendment to the accounting system in UPTD that are decentralized, it is necessary for the new Mayor Regulation in order UPTD Terminal Joyoboyo granted the right to be able to make their own accounting records without apart with Transportation Department of Surabaya. Lack of oversight of each function in carrying out its activities in UPTD Terminal Joyoboyo which raised the question in the form of certain functions on UPTD geminating, from here also arises the impression that UPTD Terminal Joyoboyo too believe with everything that is run by each of these functions. Implementation of internal control of all parts of functions in UPTD Joyoboyo Terminal will provide a positive contribution. Implementation of internal control at Terminal UPTD Joyoboyo has not done well, the need for separation of functions within the Terminal Joyoboyo UPTD continuously in order to run both effectively and efficiently.

\section{ACKNOWLEDGEMENTS}

We thank the institutions Merdeka University Merdeka Surabaya and the University Sunan Bonang Tuban for the help and support them in improving research. We also want to show our gratitude to (Yanna Ika Pratiwi and Supartini) to distribute scholarships and a lesson to us during this study. We are also very grateful for the comments fellow lecturer Merdeka University Surabaya.

\section{REFERENCES}

Baridwan, Zaki. (2002). Accounting System Preparation Procedures and Methods. V. BPFE edition. Yogyakarta.

Bodnar, George H., and William S.Hopwood. (2000). Accounting information system. Sixth edition. Salemba Four. Jakarta.

Boyton, William C., and Walter G Kell. (2003). Modern Auditing. The seventh edition. Erland. Jakarta.

IAI. (2002). Statement of Financial Accounting Standards. Salemba. Four. Jakarta.

(2005).Public Accountants Professional Standards. Salemba Four. Jakarta.

Indriantoro, Nur., Bambang Supomo. (2002). Business Research Methodology for Accounting and Management. BPFE. Yogyakarta.

Kurniawan, Panca., And Agus Purwanto. (2004). Local Taxes and Levies. Bayumedia Publishing. Poor.

Mahrus, A., Bambang Wicaksono, H., Nurlina, Cholil, H., \& Sri Wiwoho, M. (2017). Mapping of Biomass Production of Land Damage Assessment to Reduce Environmental Changes In East Java Probolinggo. In MATEC Web of Conferences (Vol. 138, p. 9004). EDP Sciences. https://doi.org/10.1051/matecconf/201713809004

Roesli, M., Heri, A., \& Rahayu, S. (2017). Authority of Land Procurement Committee In The Implementation of Compensation For Land Acquisition. YURISDIKSI: Jurnal Wacana Hukum Dan Sains, 10(2), 46-59.

Mardiasmo. (2002). Public sector accounting. Andi.Yogyakarta.

Marzuki. (2000). Research Methodology. BPFE. Yogyakarta.

Evaluation of Internal Control Activities Operating Income On Technical Implementation Unit (UPTD) 
Merinda, Dina. (2007). Evaluation of Internal Control Activities on revenue and expenditure in DAMRI Bis Surabaya. Thesis Airlangga University. Surabaya.

Moleong, Lexy J. (2002). Qualitative Research Methodology. PT Youth Rosdakarya. Bandung.

Mulyadi. (2001). Accounting System. Salemba Four. Jakarta.

East Java Provincial Government. Decision mayor of Surabaya 51 2001. About Details of duties and functions of the Department of Transportation Surabaya.

__ Surabaya City Regional Regulation No.07 of 2001. About Retribution Terminal.

__ Surabaya Mayor Regulation No.36 Year 2006 About the Organization Office of Technical Implementation Unit at the Department of Transportation Terminal Surabaya.

Siahaan, Marihot P. (2005). Local Taxes and Levies. King Grafindo. Jakarta.

Sugiyono. (2009). Understanding Qualitative Research. Alfabeta. Bandung. 